\title{
Visual Defects Associated with Vigabatrin: A Study of Epileptic Argentine Patients
}

\author{
María Cecilia Moreno, Brenda Giagante, Patricia Saidon, Silvia Kochen, \\ Jorge Benozzi, Ruth E. Rosenstein
}

\begin{abstract}
Objective: The aim of the present study was to assess visual alterations in a population of Argentine patients treated with the antiepileptic drug vigabatrin. Methods: Twenty patients receiving vigabatrin and 15 patients receiving carbamazepine were examined with automated perimetry using a Humphrey 120-point full screening strategy. In addition, scotopic flash electroretinograms were performed. Results: Of 20 patients treated with vigabatrin, two were unable to cooperate with testing. Of the remaining 18 patients, all but two showed at least one non-detected point inside the central $40^{\circ}$ of the visual field of each eye. Of the 15 carbamazepine-treated patients, three were unable to perform the study. None of the remaining 12 patients showed visual field defects. Both a- and b-wave amplitudes of the scotopic electroretinogram were significantly reduced in 12 patients receiving vigabatrin. Conclusions: Visual field defects among patients on vigabatrin therapy may occur with a higher frequency than previously recognized. The Humphrey 120-points full field screening test and electroretinography are useful tools to assess the visual dysfunction associated with vigabatrin.
\end{abstract}

RÉSUMÉ: Déficits visuels associés au vigabatrin: étude de patients argentins. Objectif: Le but de cette étude était d'évaluer les changements visuels chez un groupe de patients argentins traités par le vigabatrin, un médicament anti-épileptique. Méthodes: Vingt patients recevant du vigabatrin et 15 patients recevant de la carbamazépine ont subi une périmétrie de dépistage plein écran de 120 points au moyen de l'appareil automatisé Humphrey. De plus, des électrorétinogrammes au flash scotopique ont été effectués. Résultats: L'étude n'a pu être réalisée chez deux des 20 patients traités par le vigabatrin à cause de leur manque de coopération. Chez les 18 autres patients, tous sauf deux avaient au moins un point non détecté au champ visuel central de 40o de chaque œil. Trois des 15 patients recevant de la carbamazépine n'ont pu compléter l'étude. Aucun des 12 autres patients n'avait de déficit au niveau des champs visuels. L'amplitude des ondes a et b de l'électrorétinogramme scotopique était significativement diminuée chez 12 patients recevant le vigabatrin. Conclusions: Des anomalies du champ visuel sont peut-être plus fréquentes qu'on ne l'estimait chez les patients recevant du vigabatrin. La périmétrie automatisée Humphrey plein écran de 120 points et l'électrorétinographie sont des méthodes utiles pour évaluer la dysfonction visuelle associée au vigabatrin.

Can. J. Neurol. Sci. 2005; 32: 459-464

Vigabatrin is a highly effective antiepileptic drug used for the treatment of infantile spasm and partial seizures, particularly those unresponsive to classic antiepileptic drugs. Its efficacy is related to the ability to interfere irreversibly with $\operatorname{GABA}(\gamma-$ aminobutyric acid) transaminase activity, the enzyme involved in the catabolism of GABA, thereby increasing the levels of this neurotransmitter in the central nervous system.

Vigabatrin was thought to be a relatively free of side-effects until 1997, when Eke et al $^{1}$ described constriction of the visual fields of three patients taking vigabatrin. The loss of field persisted after the drug was stopped. Since then, persistent visual field constriction following vigabatrin treatment has been confirmed in several reports ${ }^{2-5}$ but the prevalence of visual dysfunction is still controversial. We examined visual functions in a population of Argentine epileptic patients receiving this drug. A control group of 15 epileptic patients taking carbamazepine was also evaluated.

From the Laboratory of Retinal Neurochemistry (MM, JB, RR) and Experimental Ophthalmology, Department of Human Biochemistry (BG, PS, SK), Epilepsy Center, "Ramos Mejía" Hospital, School of Medicine, University of Buenos Aires, Paraguay $2155,5^{\circ} \mathrm{P},(1121)$, Buenos Aires, Argentina.

RECEIVED JunE 9, 2004. ACCEPTED IN FINAL FORM August 2, 2005.

Reprint requests to: Ruth E. Rosenstein, Departamento de Bioquímica Humana,

Facultad de Medicina, UBA, Paraguay $2155,5^{\circ} \mathrm{P},(1121)$, Buenos Aires, Argentina 


\section{Patients And Methods}

Patients diagnosed with partial epilepsy were recruited from the Epilepsy Center, "Ramos Mejía" Hospital, Buenos Aires, Argentina. Twenty patients treated with vigabatrin and 15 patients treated with carbamazepine (who had never taken vigabatrin) consented to the study. This research adhered to the tenets of the Declaration of Helsinki and was approved by the Institutional Review Board/Ethics Committee.

\section{Ophthalmologic Examination}

A full ophthalmologic evaluation was performed to exclude other visual disorders. We recorded visual symptoms, bestcorrected visual acuities, colour vision (Ishihara 24-plate test), intraocular pressures, ocular alignment and findings on biomicroscopy and direct and indirect ophthalmoscopy.

\section{Visual Fields}

Perimetry was performed with a Humphrey field analyzer (Humphrey Systems INC, San Leandro CA, U.S.A), using the 120-Points Full Field Screening Test, which tested a field-radius of 60 degrees. The visual field examinations were performed with normal-sized pupils, i.e. without pharmacologically induced mydriasis or miosis.

The studies were performed according to the manufacturer's recommendations, using a white, size III $\left(4 \mathrm{~mm}^{2}\right)$ stimulus against a background illumination of 31.5 asb. Other test parameters were at their default values. Patient data, including age, corrective lens used (based on distance prescription with age-appropriate convex spherical add), pupil diameter, and visual acuity, were recorded. Fixation was monitored using a magnified infrared camera image every one to two minutes. Virtual cursors were manually adjusted before each test to set a fixation "window" which, if transgressed by the pupil margins, would stop the test until fixation was restored. The test time for the procedure was approximately seven minutes per eye, but rest breaks were allowed when requested. The same instructions were given to each participant.

Humphrey perimetry was considered unreliable if the blind spot could not be plotted. In order to assess the reproducibility of the visual field results, almost $30 \%$ of the patients from both groups were asked to repeat the study at least 24 hours after the first examination. In these cases, no differences between the first and the second examination were found. Two of 20 patients treated with vigabatrin, and three of 15 treated with carbamazepine, were unable to cooperate with testing. All visual field results were assessed by one ophthalmologist (JB), without knowledge of the clinical details of each patient. Visual field was considered defective when at least one non-detected point inside $40^{\circ}$ for both eyes was found.

\section{Electrophysiology}

Electroretinography (ERG) was performed with a flash stimulator; twenty minutes of dark adaptation occurred before the stimulus was presented in a scotopic ambient. The active electrode was a gold foil surface electrode placed on the skin over the infraorbital ridge near the lower eyelid. The reference electrode was placed $2 \mathrm{~cm}$ temporal to the lateral orbital rim and the ground electrode was placed slightly above the supraorbital rim. ERGs were recorded in response to $1 \mathrm{~Hz}$ flash stimulation (flash strength $3 \mathrm{~cd} / \mathrm{m}^{2}$ ). ERGs were filtered at 1.5 to $800 \mathrm{~Hz}$, and the signal was averaged. Each eye was tested separately while the second eye was occluded. The amplitudes and latencies of the a- and b- wave were measured and averaged for each patient.

\section{Results}

\section{Demographic and clinical data}

The clinical details related to the 20 vigabatrin-treated and 15 carbamazepine-treated patients are presented in Table 1 . The age range was 19 to 49 years old for the vigabatrin group and 15 to 52 years old for the carbamazepine group. The vigabatrin patients were taking the drug on a daily basis and the range of the duration of treatment was one to eight years. No patients had noted vision problems. All patients had corrected visual acuities of 20/20 in both eyes except patient 20 who had monocular congenital glaucoma. This eye was excluded from the study. No other abnormalities of visual acuity or colour vision were detected in vigabatrin-treated or carbamazepine- treated patients. Fundus inspection revealed no pathology.

The visual fields shown in Figure 1 exemplify the normal results typically observed in the carbamazepine group (patient 23 ) and the patterns of field loss seen in the vigabatrin-treated patients: nasal constriction (patient 9), more extensive nasal constriction with mild temporal constriction (patient 18), and marked generalized constriction with patchy central involvement (patient 10).

Table 2 summarizes the Humphrey perimetry results of both eyes of the patients receiving vigabatrin. Patients 8 and 12 were unable to cooperate with visual field assessment, leaving 18 assessable patients. All but two patients (patient 1 and 17) failed to detect at least one point inside the $40^{\circ}$ radius with each eye. None of the 12 assessable carbamazepine patients showed this number of non-detected points within the central $40^{\circ}$. Of the affected vigabatrin patients, $45 \%$ had marked field constrictions with central involvement and the rest had more mild constriction. The nasal field was involved in all affected eyes, and the temporal field was involved in $58 \%$ of the eyes. A right -left eye pairing (assessed as the total number of non-detected points for each eye) resulted in a highly significant correlation for all vigabatrin patients $(\mathrm{p}<0.0001)$, indicating that the dysfunction was bilateral.

No correlation between the extent of the visual field defects and the duration, daily dosage, or cumulative dosage of vigabatrin was observed. The visual field loss of one patient who received vigabatrin for two years (patient 10; Figure 1) was similar to that of patient taking vigabatrin for six years (patient 11). The two patients who had normal visual fields had taken vigabatrin for three and five years. We also found no relationship between the extent of visual field defects and the type or duration of the epileptic syndrome.

The scotopic ERG of one patient receiving carbamazepine and three patients receiving vigabatrin are shown in Figure 2. Of the 20 patients treated with vigabatrin, patient 2 failed to attend, leaving 19 assessable patients. Figure 3 shows the means ( \pm SD) of the scotopic a- and b- wave amplitudes of the 19 vigabatrintested and 15 carbamazepine-treated patients. The amplitudes were significantly reduced in patients receiving vigabatrin (for awave: control $=7.89 \pm 2.71 \mu \mathrm{V}$, vigabatrin $=5.31 \pm 2.22 \mu \mathrm{V}$, 
Table 1: Demographic and clinical details of patients

\begin{tabular}{|c|c|c|c|c|c|c|}
\hline Patient \# & Age(yrs)/Sex & $\begin{array}{c}\text { Epilepsy } \\
\text { Duration(yrs) }\end{array}$ & $\begin{array}{c}\text { VGB } \\
\text { Duration(yrs) }\end{array}$ & $\begin{array}{c}\text { Dose } \\
(\mathrm{mg} / \mathrm{d})\end{array}$ & $\begin{array}{c}\text { Concurrent } \\
\text { drugs }\end{array}$ & $\begin{array}{c}\text { Seizure } \\
\text { type }\end{array}$ \\
\hline 1 & $19 \mathrm{M}$ & 19 & 3 & 2500 & OXC, TPM & SPS, CPS, $2^{\circ} \mathrm{TCS}$ \\
\hline 2 & $23 \mathrm{M}$ & 8 & 2 & 3000 & $\mathrm{CBZ}$ & CPS \\
\hline 3 & $33 \mathrm{~F}$ & 14 & 4 & 4000 & VPA & SPS, CPS \\
\hline 4 & $43 \mathrm{M}$ & 35 & 8 & 4000 & VPA & CPS \\
\hline 5 & $28 \mathrm{~F}$ & 20 & 5 & 1500 & $\mathrm{CBZ}$ & CPS \\
\hline 6 & $20 \mathrm{M}$ & 16 & 4 & 4000 & LMT, OXC & CPS \\
\hline 7 & $30 \mathrm{~F}$ & 20 & 4 & 2000 & $\mathrm{CBZ}$ & CPS \\
\hline 8 & $25 \mathrm{M}$ & 25 & 5 & 1500 & CBZ, VPA & SPS, CPS \\
\hline 9 & $26 \mathrm{~F}$ & 18 & 2 & 2000 & $\mathrm{OXC}$ & CPS \\
\hline 10 & $49 \mathrm{~F}$ & 22 & 2 & 4000 & $\mathrm{CBZ}, \mathrm{CNZ}$ & CPS \\
\hline 11 & $25 \mathrm{M}$ & 16 & 6 & 3000 & CBZ & SPS, CPS \\
\hline 12 & $34 \mathrm{M}$ & 20 & 6 & 1500 & $\mathrm{CBZ}, \mathrm{CNZ}$ & CPS \\
\hline 13 & $23 \mathrm{M}$ & 2 & 2 & 1000 & $\mathrm{CBZ}$ & SPS, CPS \\
\hline 14 & $29 \mathrm{M}$ & 26 & 2 & 4000 & $\mathrm{CBZ}$ & CPS \\
\hline 15 & $32 \mathrm{M}$ & 22 & 1 & 1500 & $\mathrm{CBZ}, \mathrm{CNZ}$ & SPS, $2^{\circ}$ TCS \\
\hline 16 & $26 \mathrm{M}$ & 13 & 2 & 2000 & CBZ, PHT & SPS, CPS, $2^{\circ}$ TCS \\
\hline 17 & $26 \mathrm{~F}$ & 16 & 5 & 2000 & $\mathrm{CBZ}, \mathrm{CNZ}$ & CPS \\
\hline 18 & $26 \mathrm{M}$ & 5 & 2 & 3000 & CBZ & CPS \\
\hline 19 & $23 \mathrm{~F}$ & 23 & 6 & 3000 & $\mathrm{CBZ}$ & SPS,CPS, $2^{\circ} \mathrm{TCS}$ \\
\hline 20 & $20 \mathrm{~F}$ & 12 & 3 & 3500 & CBZ, DZP & SPS, CPS, $2^{\circ}$ TCS \\
\hline $\begin{array}{l}\text { VGB Patients } \\
(n=20) \\
(\text { mean } \pm \text { SD })\end{array}$ & $\begin{array}{c}28 \pm 7.4 \\
(12 \mathrm{M}, 8 \mathrm{~F})\end{array}$ & $17.6 \pm 7.55$ & $3.7 \pm 1.9$ & $2.650 \pm 1027$ & $\longrightarrow$ & - \\
\hline $\begin{array}{l}\text { Control } \\
(n=15) \\
(\text { mean } \pm S D)\end{array}$ & $\begin{array}{c}26.8 \pm 9.5 \\
(8 \mathrm{M}, 7 \mathrm{~F}\end{array}$ & $15 \pm 5.77$ & $\begin{array}{c}12 \pm 2.5 \\
(\mathrm{CBZ})\end{array}$ & $1.050 \pm 530(\mathrm{CBZ})$ & 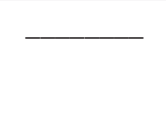 & $\underline{-}$ \\
\hline
\end{tabular}

Abbreviations: CBZ: carbamazepine; CNZ: Clonazepam; CPC: complex partial seizures; DZP: diazepam; FLE: frontal lobe epilepsy; OLE: occipital lobe epilepsy, OXC: Oxocarbazepine; PH: phenobarbital PLE: parietal lobe epilepsy; SPS: simplex partial seizures; $2^{\circ}$ TCS: secondary tonic-clonic seizures; TLE: Temporal lobe epilepsy; VGB: vigabatrin; VPA: valproic acid.

$\mathrm{p}<0.01$; for $\mathrm{b}$-wave: control $=14.16 \pm 4.76 \mu \mathrm{V}$, vigabatrin $=9.19$ $\pm 3.74 \mu \mathrm{V}, \mathrm{p}<0.01)$. A right -left eye pairing of scotopic a- and b-wave amplitudes resulted in a significant correlation for all vigabatrin patients $(\mathrm{p}<0.05$ for $\mathrm{a}$-wave, $\mathrm{p}<0.001$ for $\mathrm{b}$-wave). The $a-$ and $b$-wave amplitudes of 12 patients receiving vigabatrin fell below the lower limit of the $95 \%$ confidence interval of control patients. Of the two patients that had normal visual fields, only the a-wave amplitude from patient 17 was abnormal. The scotopic a-wave and b-wave latencies showed no significant differences for control and vigabatrin-treated patients.

\section{Discussion}

In this study, $89 \%$ of the patients taking vigabatrin failed to detect at least one point in the central $40^{\circ}$ of the visual fields of both eyes on the Humphrey 120-point full field screening test.
No carbamazepine-treated patients had abnormal fields by this criterion. The vigabatrin-treated patients showed a similar number of non-detected points in both eyes. As in previous studies, the nasal field was predominantly affected and no patients complained of visual symptoms.

The prevalence of visual field constriction associated with vigabatrin has varied widely in previous reports, ranging from less than $0.1 \%$, as initially reported by the manufacturer ${ }^{6}$, to more than $50 \%, 3,7,8$ The results of the present study showed a higher prevalence than that in most previous studies. The higher prevalence may be related to our use of a full field screening technique rather than the more detailed, but slower and more spatially constricted technique of full threshold estimations. The screening technique is less quantitative than the threshold technique but may be more sensitive in detecting vigabatrin- 


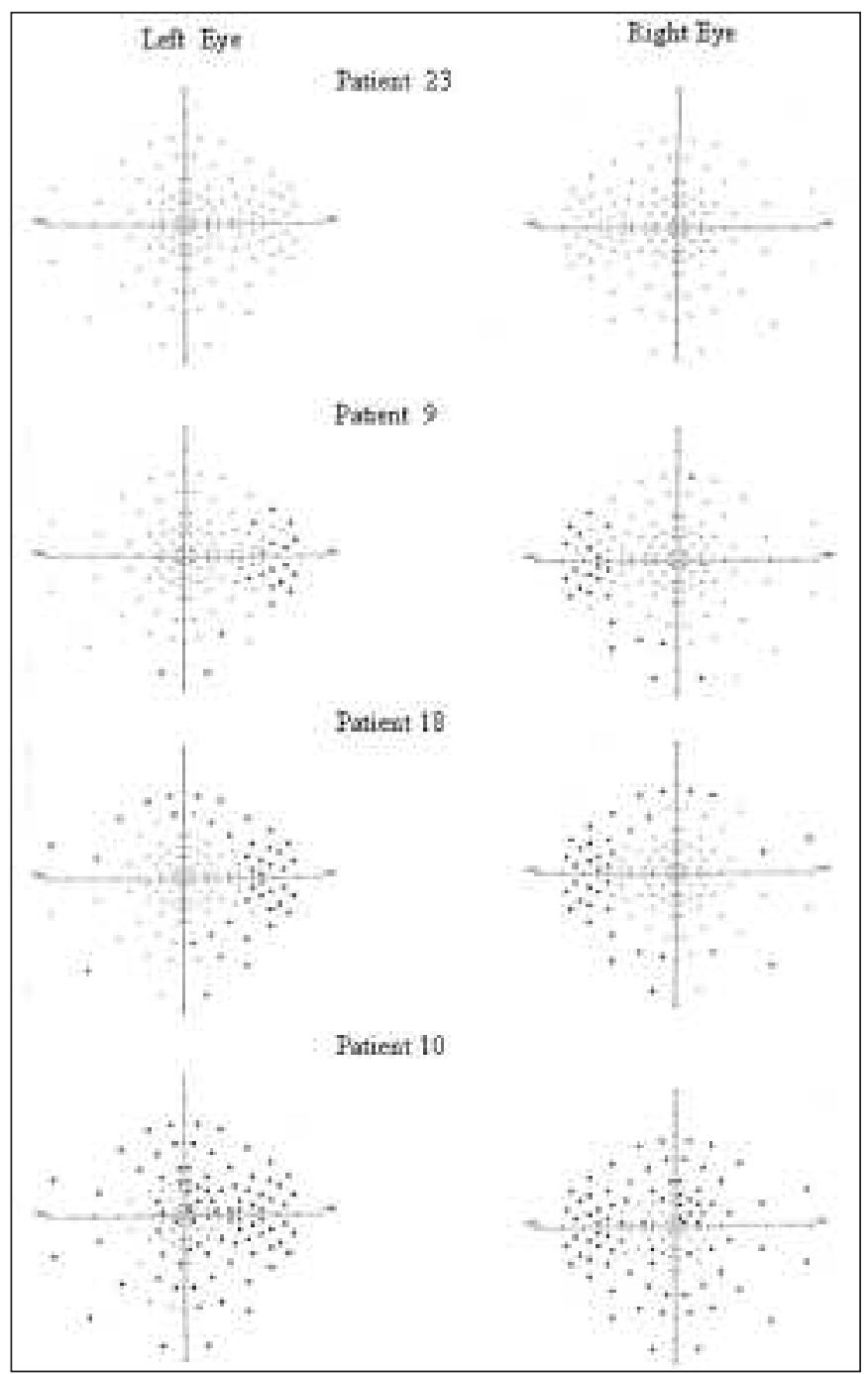

Figure 1: The results of Humphrey 120-point full field screening test of one patient treated with carbamazepine and three patients treated with vigabatrin. The control patient (patient 23) has normal visual field whereas the vigabatrin patients show peripheral nasal constriction (patient 9), more extensive nasal constriction with mild temporal constriction (patient 18), and marked generalized constriction with patchy central involvement (patient 10).

related field loss. The Humphrey screening technique assesses a radius of 60 degrees and monitors false-positive and falsenegative responses and fixation behavior. The stimuli are above threshold and reliably detect major changes, whereas threshold automated perimetry may be less reliable for testing points outside a radius of 30 degrees. Although we tested a $60^{\circ}$ radius, our criterion to define an abnormal field was based on points missed within a $40^{\circ}$ radius. Thus, methodological differences may account for the higher prevalence of visual field constriction. This is supported by the observation that, if only the central 30 degrees is considered, the prevalence of field loss in our population is close to that of previous reports. Using similar methodology to ours, Midelfart et $\mathrm{al}^{9}$ recently reported a similar frequency of visual field defects $(86 \%)$ in a group of eighteen epileptic children treated with vigabatrin.
In this study, scotopic ERGs showed a significant reduction of both a- and b-wave amplitudes in vigabatrin-treated patients; over $60 \%$ had amplitudes that fell bellow the lower confidence limit of carbamazepine-treated patients. In previous reports, the prevalence of ERG dysfunction in vigabatrin-treated patients has varied from $0^{7}$ to $100 \% .{ }^{8}$ Most ERG abnormalities have been observed under photopic conditions, implicating cone dysfunction. ${ }^{10-12}$ Studies by Daneshvar et $\mathrm{al}^{13}$ and Miller et $\mathrm{al}^{8}$ have also shown reduction of $b$-wave amplitudes under scotopic conditions. In the present study, no correlation was observed between the scotopic ERG abnormalities and the visual field results. Miller et al, ${ }^{8}$ however, observed a strong correlation between cone ERG amplitudes and field constriction as measured by kinetic perimetry. The results of this study confirm that scotopic ERG abnormalities are common in vigabatrintreated patients and may be a useful indicator of retinal dysfunction, especially in patients for whom reliable perimetry cannot be performed.

The retinal locus and mechanism that account for the visual disturbance associated with vigabatrin therapy are not well understood. Dysfunction of both the cone and the rod systems

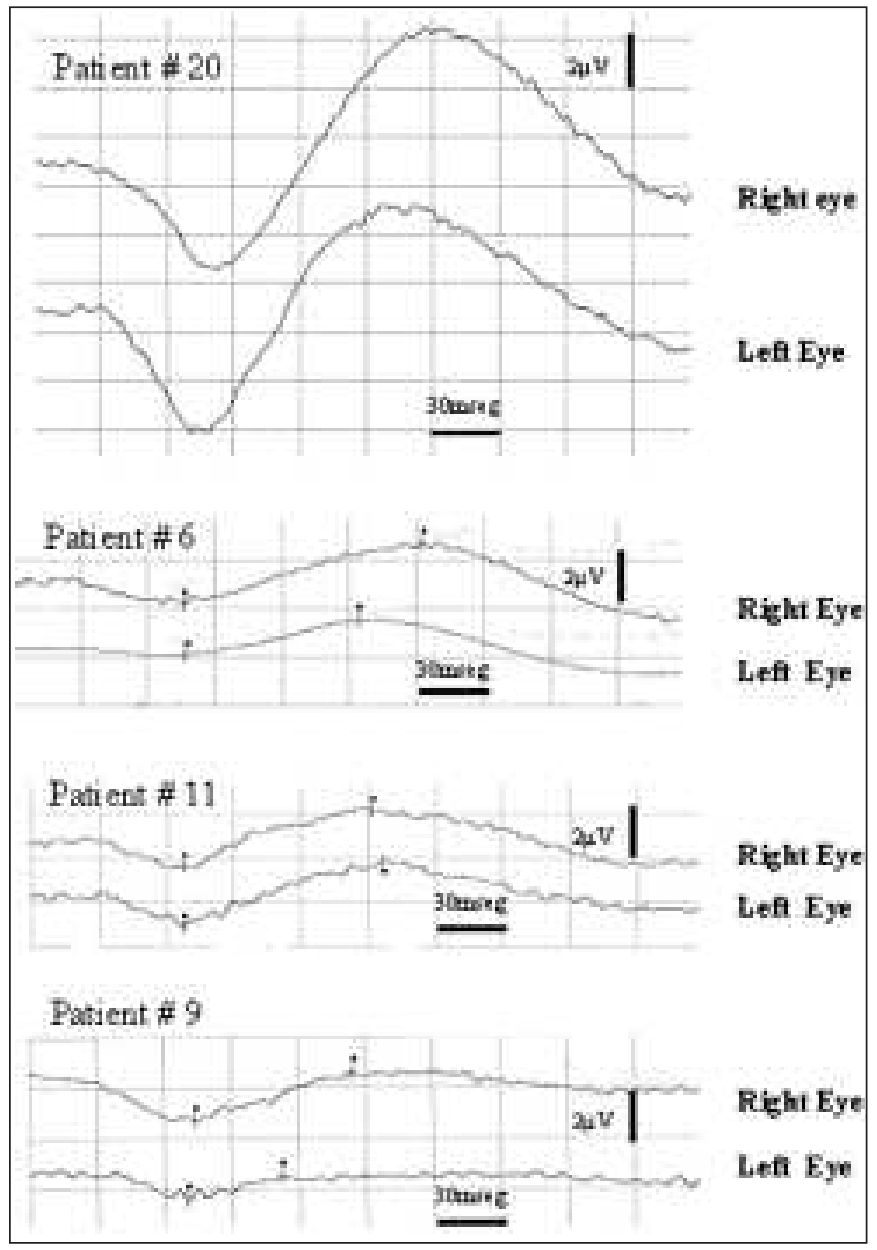

Figure 2: Scotopic ERGs of one control patient (patient 20), which is normal, and three patients treated with vigabatrin (patients 6, 9 and 11), which show decreased $a$ - and $b$-wave amplitudes. 
Table 2: Number of non-detected points for both eyes on Humphrey 120-point full field screening test

\begin{tabular}{|c|c|c|c|c|}
\hline VGB Patients & $\begin{array}{c}\text { Total } \\
(\mathrm{n}=240)\end{array}$ & $\begin{array}{c}\text { Inside } 40^{\circ} \\
(\mathrm{n}=208)\end{array}$ & $\begin{array}{c}\text { Nasal } \\
(\mathrm{n}=148)\end{array}$ & $\begin{array}{c}\text { Temporal } \\
(\mathrm{n}=90)\end{array}$ \\
\hline 1 & 1 & 1 & 1 & 0 \\
\hline 2 & 12 & 2 & 12 & 0 \\
\hline 3 & 42 & 16 & 38 & 4 \\
\hline 4 & 78 & 36 & 70 & 8 \\
\hline 5 & 13 & 6 & 8 & 5 \\
\hline 6 & 35 & 14 & 34 & 1 \\
\hline 7 & 25 & 5 & 24 & 1 \\
\hline 9 & 43 & 20 & 40 & 3 \\
\hline 10 & 131 & 73 & 88 & 43 \\
\hline 11 & 140 & 82 & 98 & 42 \\
\hline 13 & 99 & 58 & 87 & 22 \\
\hline 14 & 29 & 19 & 22 & 7 \\
\hline 15 & 97 & 51 & 69 & 28 \\
\hline 16 & 67 & 23 & 54 & 13 \\
\hline 17 & 3 & 0 & 3 & 0 \\
\hline 18 & 81 & 50 & 67 & 14 \\
\hline 19 & 129 & 65 & 87 & 42 \\
\hline 20 & 40 & 21 & 23 & 17 \\
\hline VGB & 59.2 & 30.1 & 45.9 & 13.9 \\
\hline $\begin{array}{l}\text { Patients } \\
(n=18) \\
(\text { mean } \pm S D)\end{array}$ & \pm 45.3 & \pm 26.5 & \pm 32.3 & \pm 15.3 \\
\hline $\begin{array}{l}\text { Control } \\
(n=12) \\
(\text { mean } \pm S D)\end{array}$ & $\begin{array}{c}1.5 \\
\pm 2.1\end{array}$ & $\begin{array}{c}0.2 \\
\pm 0.4\end{array}$ & $\begin{array}{c}0.6 \\
\pm 1.2\end{array}$ & $\begin{array}{c}0.8 \\
\pm 1.4\end{array}$ \\
\hline
\end{tabular}

Patient 8 and 12 and three CBZ patients were unable to cooperate with visual field testing. The left eye of patient 20 was excluded from the study. $\mathrm{VGB}=$ vigabatrin, $\mathrm{CBZ}=$ carbamazepine, $\mathrm{SD}=$ standard deviation.

has been postulated. ${ }^{10,14}$ Whether the dysfunction results from nonspecific toxicity or a chronic increase in retinal GABA levels remains an open question. GABA is a major inhibitory neurotransmitter of the vertebrate retina. In several species, the horizontal and amacrine cells are the principal GABAergic neurons in the retina. ${ }^{15,16}$ Perfusion with GABA agonists in the cat alters the responses of horizontal, amacrine, and ganglion cells. ${ }^{17}$ In albino rats (but not pigmented rats), vigabatrin has a dose-dependent effect on the retina, characterized by disruption of the outer nuclear layer, which contains the photoreceptor nuclei. $^{18}$ GABA selectively affects components of the ERG. In rabbits, low concentrations of extracellular GABA enhance aand $b$-wave amplitudes, whereas high concentrations reduce the b-wave amplitude and have no effect on the a-wave amplitude. ${ }^{19}$ In rats, the inactivation of GABA transaminase is greater in the retina than in the brain ${ }^{20}$ and the retina does not develop tolerance to vigabatrin, unlike the brain and the spinal cord..$^{21}$ Reduction of b-wave amplitude under scotopic and photopic conditions could be the result of GABA-induced Müller cell dysfunction. ${ }^{22}$

The results of this study provided further support for a casual relationship between vigabatrin treatment and a specific pattern

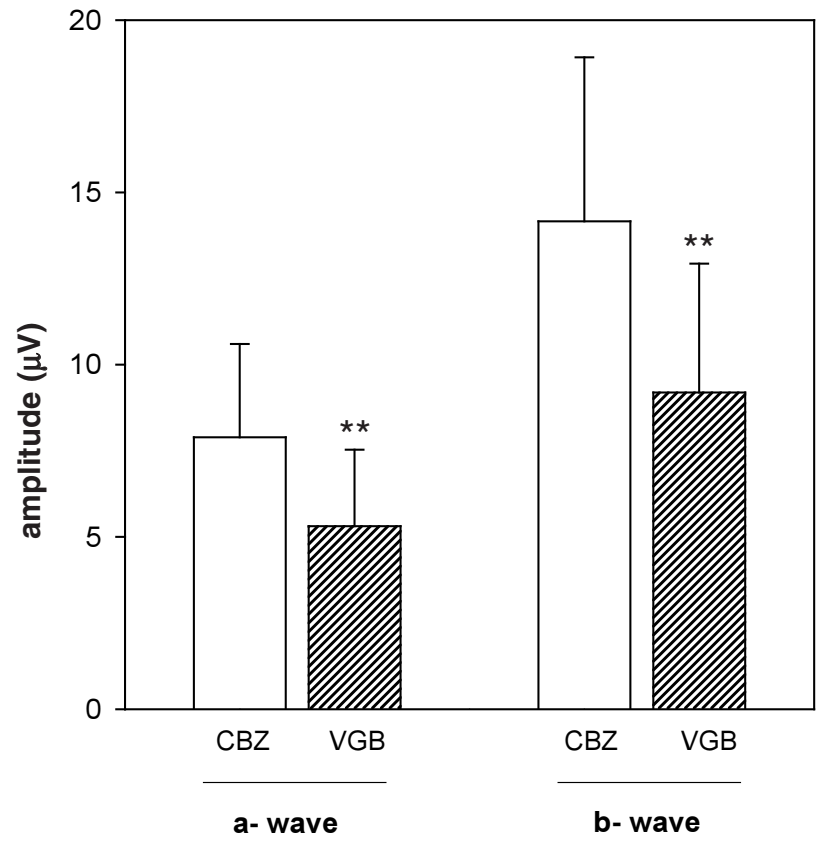

Figure 3: Mean scotopic ERG a- and b-wave amplitudes (+1SD) of control (carbamazepine-treated) patients $(C B Z ; n=15)$ and vigabatrintreated patients $(V G B ; n=19)$ showing a significant reduction in the $V G B$ group $\left({ }^{* *} p<0.01\right.$ by Student's $t$ - test $)$.

of visual field loss and electroretinographic dysfunction. Our results suggest that patients receiving vigabatrin should have their visual fields monitored regularly and that the Humphrey 120-point screening technique and electroretinography are useful monitoring tools.

\section{ACKNOWLEDGMENTS}

The authors thank Dr. Diego Golombek and Miss Sarah Howard for helpful discussion of this manuscript. This research was supported by grants from Agencia Nacional de Promoción Científica y Tecnológica (ANPCyT), Fundación Antorchas, "Ramón Carrillo- Arturo Oñativia" fellowship, National Health Office, Argentina, and Sigma Xi Organization.

\section{REFERENCES}

1. Eke T, Talbot JF, Lawden MC. Severe persistent visual field constriction associated with vigabatrin. BMJ 1997; 314: 180-181.

2. Harding GF, Robertson KA, Edson AS, et al. Visual electrophysiological effect of a GABA transaminase blocker. Doc Ophthalmol 1998; 97: 179-188.

3. Kalviainen R, Nousiainen I, Mantyjarvi, et al. Vigabatrin, a GABAergic antiepileptic drug, causes concentric visual field defects. Neurology 1999; 53: 922-926.

4. Toggweiler S, Wieser HG. Concentric visual field restriction under vigabatrin therapy: extent depends on the duration of drug intake. Seizure 2001; 10: 420-423.

5. Mauri-Llerda JA, Iniguez C, Tejero-Juste C, et al. Visual field changes secondary to vigabatrin treatment. Rev Neurol 2000; 31 : 1104-1108.

6. Martinez C, Noack H. The risk of visual field defects and the use of vigabatrin. Denham: Hoechst Marion Roussel, 1997. (Internal report.) 
7. Lawden MC, Eke T, Degg C, et al. Visual field defects associated with vigabatrin therapy. J Neurol Neurosurg Psychiatry 1999; 67: 716-722.

8. Miller NR, Johnson MA, Paul SR, et al. Visual dysfunction in patients receiving vigabatrin: clinical and electrophysiologic findings. Neurology 1999; 53: 2082-2087.

9. Midelfart A, Midelfart E, Brodtkorb E. Visual field defects in patients taking vigabatrin. Acta Ophthalmol Scand 2000; 78: 580584.

10. Krauss GL, Johnson MA, Miller NR. Vigabatrin-associated retinal cone system dysfunction: electroretinogram and ophthalmologic findings. Neurology 1998; 50: 614-618.

11. Harding GF, Wild JM, Robertson KA, et al. Separating the retinal electrophysiologic effects of vigabatrin: treatment versus field loss. Neurology 2000; 55: 347-352.

12. Johnson MA, Krauss GL, Miller NR, et al. Visual function loss from vigabatrin: effect of stopping the drug. Neurology 2000; 55: 4045 .

13. Daneshvar H, Racette L, Coupland SG, et al. Symptomatic and asymptomatic visual loss in patients taking vigabatrin. Ophthalmology 1999; 106: 1792-1798.

14. Comaish IF, Gorman C, Brimlow GM, et al. The effects of vigabatrin on electrophysiology and visual fields in epileptics: a controlled study with a discussion of possible mechanisms. Doc Ophthalmol. 2002; 104: 195-212.
15. Mosinger JL, Yazulla S, Studholme KM. GABA-like immunoreactivity in the vertebrate retina: a species comparison. Exp Eye Res 1986; 42: 631-644.

16. Lopez-Costa JJ, Goldstein J, Pecci-Saavedra J, et al. GABA release mechanism in the golden hamster retina. Int J Neurosci 1999; 98 : 13-25.

17. Frumkes TE, Nelson R. Functional role of GABA in cat retina: I. Effects of GABAA agonists Vis Neurosci 1995; 12: 641-650.

18. Butler WH, Ford GP, Newberne JW. A study of the effects of vigabatrin on the central nervous system and retina of Sprague Dawley and Lister-Hooded rats. Toxicol Pathol 1987; 15: 143148.

19. Gottlob I, Wundsch L, Tuppy FK. The rabbit electroretinogram: effect of GABA and its antagonists. Vision Res 1988; 28: 203210.

20. Sills GJ, Patsalos PN, Butler E, et al. Visual field constriction: Accumulation of vigabatrin but not tiagabine in the retina. Neurology 2001; 57: 196-200.

21. Neal MJ, Shah MA. Development of tolerance to the effects of vigabatrin (gamma-vinyl-GABA) on GABA release from rat cerebral cortex, spinal cord and retina. Br J Pharmacol 1990; 100: 324-328.

22. Coupland SG, Zackon DH, Leonard BC, Ross TM. Vigabatrin effect on inner retinal function. Ophthalmology 2001; 108: 1493-1496. 